\title{
Use of non-destructive eddy current technique to detect simulated corrosion of aircraft structures
}

\section{Zistovanie simulovanej korózie leteckých konštrukcií metódu vírivých prúdov}

\author{
Janovec M., Čerňan J., Škultéty F. \\ University of Zilina, Department of Air Transport \\ E-mail: michal.janovec@fpedas.uniza.sk
}

The article deals with the issue of non-destructive testing of riveted joints. In the article, the authors used a non-destructive eddy current array technique, which was applied to detect simulated corrosion in the field of aircraft riveted joints of aluminum sheets. In aircraft maintenance, the eddy current method is used to control the outer surface of the aircraft skin, especially the areas around the riveted joints. This method makes it possible to detect hidden cracks and corrosion that may occur during aircraft operation. Especially hidden are hidden cracks and corrosion of aircraft structures, which cannot be detected during a visual inspection of the aircraft. The aim of the experimental measurements was to reveal simulated corrosion in the area of riveted joints formed on the experimental sample. Corrosion was simulated by gluing aluminum powder to the surface of the aluminum sheets from which the sample was made. The simulated corrosion in the second and third layers of the riveted sample was reliably detected. The settings, the method of control and the results of measurements are given in the article in the experimental part and the results of measurements. Measurements were performed using a defectoscope with an ECA measurement module, with appropriate measuring probes suitable for this type of inspection.

\section{INTRODUCTION}

The eddy current method is one of the methods of non-destructive evaluation. Non-destructive testing (NDT) plays an important role in the safety of aircraft components and structures. As the term implies, NDT refers to test methods that use special devices and approaches to inspect an object without damaging it or affecting its future utility. NDT is mainly used to detect and characterize hidden defects or damage to critical components or structures, but also has applications in dimensional measurements and evaluation of some material properties. It is used to ensure the structural integrity of aircraft, as well as nuclear reactors, high-speed trains, platforms, bridges, cranes, gas and oil pipelines and many other structures. NDT is used during production as a quality control tool to ensure that materials and
Článok sa zoberá problematikou nedeštruktívneho testovania leteckých nitovaných spojov. V článku autori využili nedeštruktivnu techniku vírivých prúdov, ktorá bola aplikovaná na zistenie simulovanej korózia v oblasti leteckých nitovaných spojov hlinikových plechov. Vúdržbe lietadiel sa metóda vírových prúdov použiva na kontrolu vonkajšieho potahu plášta lietadla, hlavne teda oblastí v okoli nitovaných spojov. Táto metóda umožňuje odhalit' skryté trhliny a koróziu, ktoré môžu vzniknút' počas prevádzky lietadiel. Nebezpečné sú hlavne teda skryté trhliny a korózia leteckých konštrukcii, ktoré nie je možné odhalit' pri vizuálnej prehliadke lietadla. Ciel'om experimentálnych merani bolo odhalenie simulovanej korózie v oblasti nitovaných spojov, vytvorených na experimentálnej vzorke. Korózia bola simulovaná nalepením hliníkového prášku na povrch hliníkových plechov, z ktorých bola vzorka vyrobená. Simulovaná korózia $v$ druhej a tretej vrstve nitovanej vzorke, bola spol'ahlivo odhalená. Nastavenia, spôsob kontroly, výsledky meraní sú $v$ článku uvedené $v$ experimentálnej časti a výsledkoch merani. Merania boli vykonané pomocou defoktoskopu s modulom pre meranie ECA, s príslušnými meracími sondami, vhodnými na takýto typ kontroly.

finished products are free from internal defects or that the abnormalities detected are below a size that would be considered potentially harmful. NDT is used during production as a quality control tool to ensure that materials and finished products are free from internal defects or that the abnormalities detected are below a size that would be considered potentially harmful. NDT is also used during the operation of objects to detect cracks, corrosion, or other forms of degradation and damage that may cause components or systems to fail, or impair their proper functioning [1]. In addition, NDT is used as a research tool in a laboratory to study certain material properties, internal properties, or production processes. It is also used in mechanical or environmental testing (testing of resistance to external influences) of samples or structures in full to monitor material deformation, deterioration, crack propagation and failure [2,3]. 


\section{CORROSION OF AIRCRAFTS STRUCTURES}

The issue of protection of aircraft construction against corrosion is part of aviation legislation and regulations. One important document in this area is Acceptable Means of Compliance AMC 20-20 „Continuing Structural Integrity Programme“ (AMC - Acceptable Means of Compliance).

Document Acceptable Means of Compliance AMC 20-20 „Continuing Structural Integrity Programme“ has been issued as an Annex to EASA Director Decision No. AMC 20-20 (Annex 4) also contains guidelines for the development of a program for the prevention and control of corrosion in aeronautical engineering. The guidelines contain instructions for aircraft operators and approved development organizations (in cooperation with competent authorities) for the development and implementation Corrosion Prevention and Control Programme (CPCP) for aircraft maintained in accordance with Part M M.A.302 maintenance programs.

The CPCP program is a comprehensive and systematic approach to corrosion control that the permissible load on the aircraft structure does not degrade below the required level of continuing airworthiness.

Corrosion Prevention and Control Programme (CPCP) contain:

- basic tasks for corrosion control / inspection,

- definition of corrosion level (levels 1, 2 and 3),

- border and re-inspection intervals for work in each area or zone of aircraft,

- specific procedures for cases where corrosion damage exceeds level 1 in each area or zone [4].

\section{Corrosion levels}

Corrosion level 1 is defined as:

- corrosion that has occurred between consecutive corrosion checks that is local and can be repaired/removed within the permissible limits,

- corrosion damage that is local and exceeds the allowable limit, but can be considered as an event that is not operationally typical of any other aircraft from the fleet,

- the operator's experience points to only slight corrosion between successive corrosion checks.

Corrosion level 2 - it is corrosion that has occurred between any two consecutive checks and requires a simple overhaul.

Corrosion level 3 - is the corrosion that is generated during the first or subsequent corrosion control and requires the operator to give urgent/immediate attention to the continuing airworthiness.

\section{Corrosion Prevention and Control Programme}

Corrosion Prevention and Control Programme is based on processing Baseline Programme. The objective of the Basic Program is to establish corrosion control requirements in aircraft design for level 1 or (better) during the technical life of the aircraft. This program should include core tasks, border implementation and control intervals. It should also include procedures for notification of findings and associated data by the Competent Level 2 and Level 3 Corrosion Authority and the necessary actions to reduce future Level 1 findings.. In order to effectively elaborate the basic program, the following must be considered in particular facts:

- flight and maintenance history data for the aircraft type and similar aircraft types

- corrosion properties of materials used in aircraft construction, protective treatments used,

- general procedures applied during design and maintenance,

- local and extensive corrosion.

\section{The basic program for the prevention and protection of corrosion is processed by both the type certificate holder and the aircraft operator.}

The Aircraft Operator should pay particular attention to specific parts of the aircraft, such as aircraft components, when processing and defining tasks and control intervals, gas outlet points, battery location points, toilet surroundings, underframe, undercarriage, outer surface, water collection/retention points, engine entry points, electronic and avionic equipment location points, interior spaces where flight control devices are located [5].

\section{EXPERIMENTAL PART}

The experimental measurements described in this article are aimed at non-destructive inspection of aircraft riveted joints. In the area of riveted joints, corrosion of riveted sheets is simulated by fine aluminum powder. Eddy current technology (ECA) was used to inspection of the produced riveted joints [6].

ECA is a method that allows electronic control of eddy current coils placed side by side in a single probe assembly. Data acquisition is performed by multiplexing the eddy current coils in a special pattern to avoid mutual inductance between the individual coils. Most conventional eddy current flaw detection techniques can be reproduced with an ECA inspection. With the benefits of single-pass coverage, and enhanced imaging capabilities, ECA technology provides a remarkably powerful tool and significant time savings during inspections. 
The ECA method uses the same basic principles as conventional eddy current technology. The alternating current through the coil creates a magnetic field. When the coil is positioned above the conductive portion, opposing alternating currents (eddy currents) are formed. In the event of a failure, the eddy current path is interrupted and the eddy current change is recorded by the measuring coil. In the case of ECA probes, each individual coil in the probe generates a signal relative to the phase and amplitude of the structure below it. These data refer to the coded position and time and are graphically represented as a C-scan (top view) image. The C-scan display enables quick orientation on the test area and good interpretation of the resulting data. Each separate eddy current coil in the probe produces a signal relative to the phase and amplitude of the structure below it. This data refers to the coded position and time and is graphically represented as a C-scan image. For coils that are affected by a crack or corrosion that starts from the thread hole, the C-scan display shows the amplitude change. For coils that do not notice any change, the color display on the C-scan display remains constant [7].

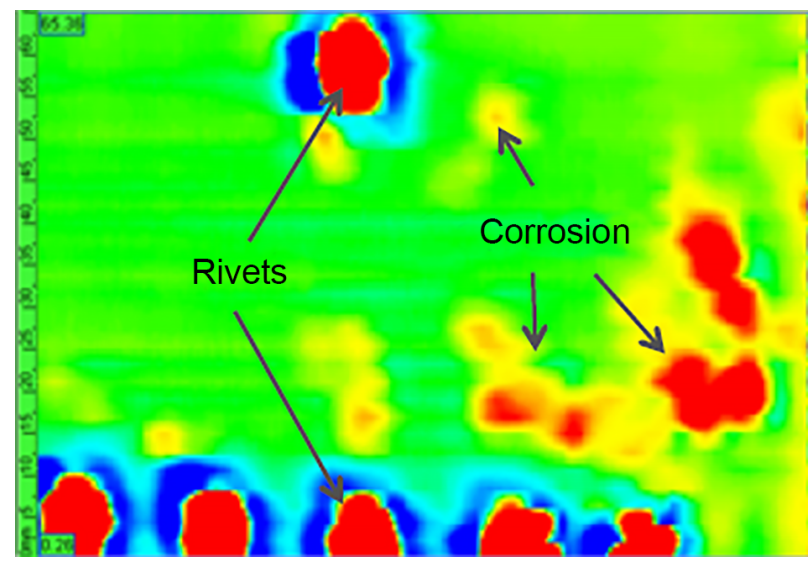

Fig. 1. Imaging of C-scan of riveted structure and corrosion Obr. 1. Zobrazenie C-scan nitovaných spojov a korózie



Fig. 2. Defectoscop Olympus OmniScan MX Obr. 2. Defektoskop Olympus OmniScan MX
Olympus OmniScan MX was used to measure rivet joints. This device is a modular and portable test unit. An eddy current module was used in the instrument.

The instrument can be used for manual as well as automated inspections. The number of channels of the device is 32 with internal multiplexing or 64 channels with external multiplication. The OmniScan connector has a probe ID function that allows the physical detection and recognition of the probe of the connected probe. This function is to set the $\mathrm{C}$-scan resolution of the ECA probes and read the correct probe parameters.

To the defectoscop Olympus were used ECA probes SBB-051-150-032 ad SAB-067-005-032 (shown in Fig. 3) which are suitable for such inspection of riveted joints.

For the control measurements, several types of riveted joints were created to simulate the defined damage. The riveted joints were made of aluminum non-anodized sheets $200 \times 1000 \times 1 \mathrm{~mm}$. Aluminum solid rivets STN 022311 head $4 \times 6 \mathrm{~mm}$ were used as fasteners.

In the area of riveted joints, the faults caused by corrosion of aluminum sheet were simulated. Aluminum powder was glued to the sheet surface, simulating different forms of corrosion between the riveted sheets. Very fine aluminum powder CAS: 7429-90-5 was used to simulate corrosion. The powder specification is described



Fig. 3. ECA probes Olympus

Obr. 3. ECA sondy Olympus

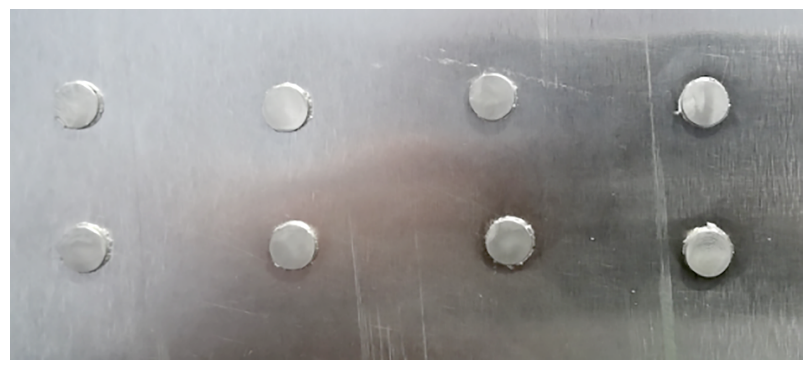

Fig. 4. Created riveted joints

Obr. 4. Vytvorené nitované spoje 
in Table 1. The aluminum powder was adhered to the sheet surface with a flexible, gel-like adhesive based on a solvent-free FLEXTEC polymer.

Tab. 1. Aluminum powder specifications / Špecifikácia hlinikového prášku

\begin{tabular}{|c|c|}
\hline \multicolumn{2}{|c|}{ Aluminum powder CAS: $7429-90-5$} \\
\hline \multicolumn{2}{|c|}{$\begin{array}{l}\text { - fine powder silver gray, made of aluminum of min. } 99 \% \text {, } \\
\text { active aluminum at least } 98 \% \\
\text { - the average particle size of D50 is } 51.47 \text { microns - } \\
\text { - spherical-shaped particles }\end{array}$} \\
\hline \multicolumn{2}{|c|}{ Specifications: } \\
\hline $\mathrm{Fe}$ & $\max .0,14 \%$ \\
\hline $\mathrm{Si}$ & $\max .0,07 \%$ \\
\hline $\mathrm{Cu}$ & $\max .0,001 \%$ \\
\hline Humidity & $\max .0,2 \%$ \\
\hline Bulk density & $0,95-1,24 \mathrm{~g} \mathrm{~cm}^{-3}$ \\
\hline Melting point & $661{ }^{\circ} \mathrm{C}$ \\
\hline Dust flash point & $661{ }^{\circ} \mathrm{C}$ \\
\hline Burning temperature & around $2500{ }^{\circ} \mathrm{C}$ \\
\hline
\end{tabular}

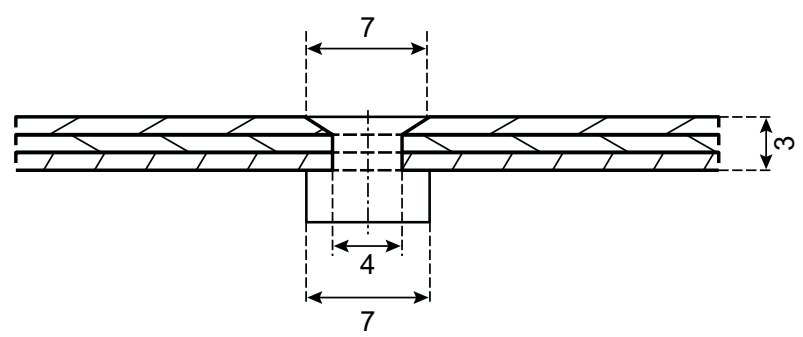

Fig. 5. Schematic representation of formed riveted joints Obr. 5. Zobrazenie nitovaného spoja $v$ reze



Fig. 6. Demonstration of aluminum powder adhered around rivet holes

Obr. 6. Hliníkový prášok nalepený v oblasti otvorov pre nity

\section{MEASUREMENT RESULTS}

Eddy Current Array (ECA) method is used to inspect produced riveted joints. ECA is a state-of-the-art eddy current method that utilizes several coils placed in one probe assembly. Such an arrangement allows greater coverage of the control area while maintaining high resolution, improves error detection and error size by C-Scan display. The C-scan display is a graphical representation of the eddy current signal depending on the probe position. Analysis of the obtained C-scan allows to detect inhomogeneities in the material based on preset conditions, e.g. by comparison with calibration scales or by comparison of simulated signals.

Before the measurement, it is necessary to deter-mine the reference signals of the probe, which will be compared with the actual measured signals in which cracks or corrosion may occur. The calibration process should be performed before each measurement. The ECA method is so-called comparative method. This means that two signals must be compared. The differential of the two signals gives a different response, which is important for signal analysis and evaluation. By comparing these signals it is possible to give and confirm the conclusion of any measurement. All calibration measurements were performed on calibration samples. Calibration samples means a block sample of the same material as the actual structure with the presence of a crack of defined dimensions. The resulting signals are displayed after excitation and are the basic signals for evaluating other unknown signals obtained by measuring the true structure [8].

In this particular example, corrosion detection gives these values:

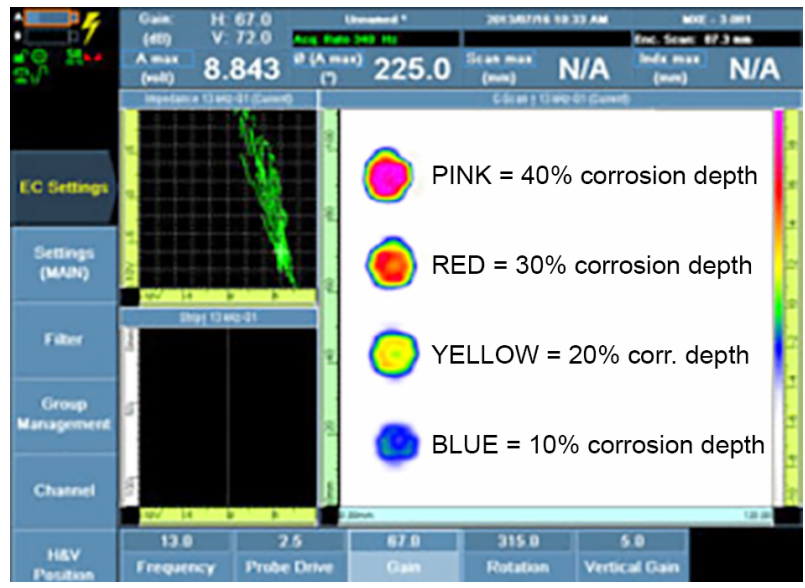

Fig. 7. Area and Depth Color Calibration

Obr. 7. Kalibračné farby určujúce plochu a híbku korózie

The measurement, which is evaluated in more detail in the article, is the control of the simulated corrosion in the last third layer (sheet) of the riveted sample. The rivet regions specified in Figure 8 were checked. 


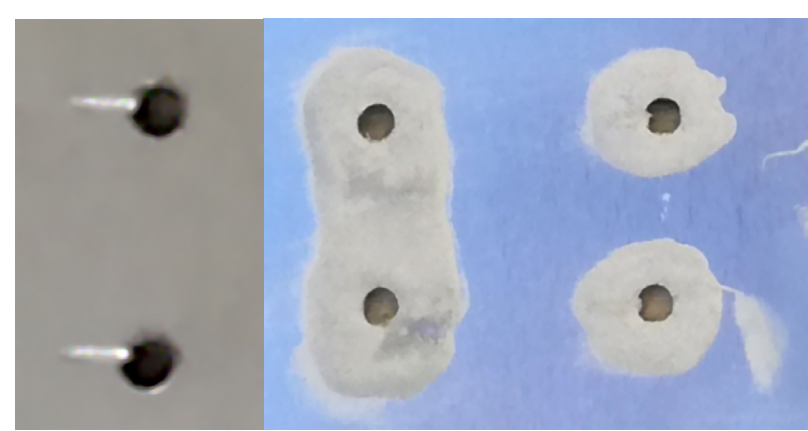

Fig. 8. Shape of bonded aluminum powder, ECA inspected Obr. 8. Tvar nalepeného hliníkového prášku podrobeného kontrole ECA

The area of the riveted sample shown in Figure 8 was subjected to the Eddy Current Aray inspection. Four areas of rivets were inspected in the vicinity of which aluminum powder corrosion was simulated. In the area of the two rivet holes, two longitudinal notches were made, simulating cracks in the area of the thread hole. The length of the incisions was $4 \mathrm{~mm}$, the width was $1 \mathrm{~mm}$ and the depth ranged from $1 \mathrm{~mm}$ to about $0.1 \mathrm{~mm}$. The dimensions of the created notches cannot be precisely

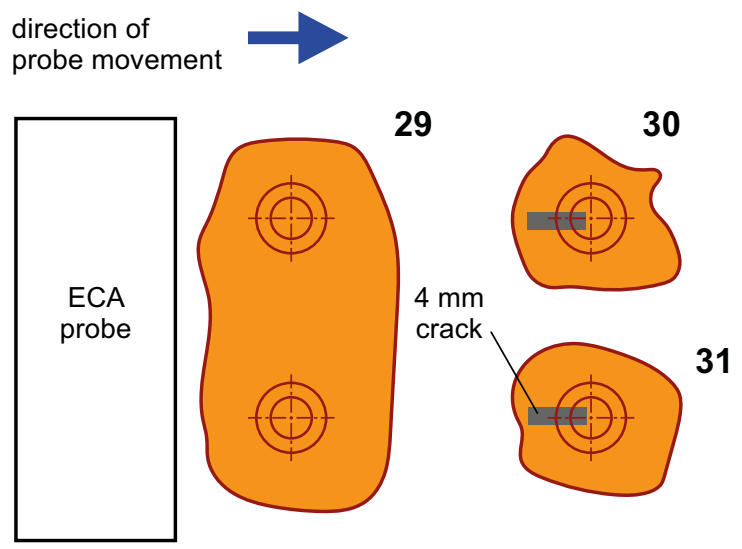

Fig. 9. Schematic illustration of the control method Obr. 9. Schematické znázornenie spôsobu kontroly

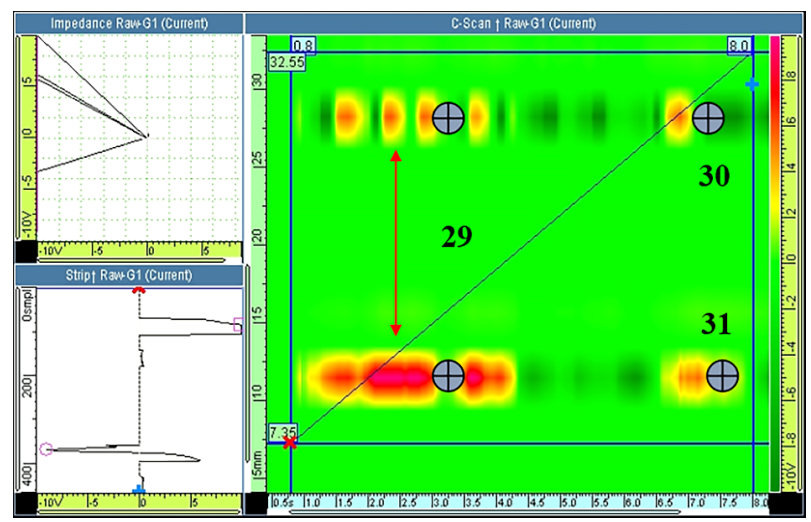

Fig. 10. The resulting C-Scan from the Olympus OminScan MX flaw detector

Obr. 10. Výsledné C-scan zobrazenie kontrolovanej oblasti vyhotovené prístrojom Olympus OmniScan MX determined because they were created manually. A microgrinder with a $1 \mathrm{~mm}$ thick grain wheel was used to make the incisions. The created notches are shown in Figure 8 on the right. Probe SAB-067-005-032 was used for scanning. The parameters set during the measurement were as follows: $5 \mathrm{kHz}$ excitation frequency, $85 \mathrm{~dB}$ gain, without filter and multiplexer off. The strip-shaped aluminum powder formed between the rivets (29) was also reliably detected only in the area of the rivets as in the previous measurement. At rivets 30 and 31, the aluminum powder was reliably detected. The created $4 \mathrm{~mm}$ long and $1 \mathrm{~mm}$ wide crack on the left side of the rivets merged with the aluminum powder and was not shown significantly. From an impedance signal having a range of $19 \mathrm{~V}$ and comparing to the impedance value obtained in a calibration measurement, it is possible to estimate the depth of the aluminum powder indications from 2 to $2,5 \mathrm{~mm}$.

\section{DISCUSSION ON MEASUREMENT RESULTS}

The inspection process must be started by setting the input parameters and specifying the requirements. The input parameters must be set with respect to the expected controlled structure. When measuring the riveted joints, the input parameters for checking the $3 \mathrm{~mm}$ thick riveted joints were checked. In particular, it was necessary to set a suitable frequency for scanning the first, second and third layers of the riveted joint. Measurement data can be obtained numerically or experimentally. For further work it is necessary to process the obtained information in some way. By evaluating the difference signal, useful data is obtained. This procedure is repeated to record all scan positions of the ECA probe. The result is a graphical representation of the eddy current signal depending on the position of the probe, which provided an overall view of the scanned structure of the riveted joints.

C-scan imaging at all measurements of the simulated third layer faults provided an image corresponding to the actual fault dimensions. However, deviations have occurred in the eddy current waveforms from which the failure depth is determined. In this case, the SBB-051-150-032 probe used reached the maximum control depth at which simulated failures were detected. The information obtained from the non-destructive inspection of riveted joints by the ECA method is useful for checking aircraft in exceptional cases (for damage caused during operation), for checking critical points on small sport aircraft for aerobatic training, for corrosion and damage to older aircraft, etc.

For the correct interpretation of the results of eddy current measurements, it is necessary to follow the following inspection procedures, or take into account possible limitations during the inspection: 
Correct handling of the measuring probe - when moving the probe over the controlled material, care must be taken not to change the distance of the spool from the material. Moving the probe away from the controlled material would cause the value of the probe signal to change, leading to degraded measurement. Therefore, during the manual inspection, make sure that the measuring probe is correctly pressed against the test surface.

The influence caused by a change in geometry, or a foreign object - care must be taken to ensure that there is no foreign object in the vicinity of the inspected object during the inspection, which may affect the measurement results, e.g. by changing the conductivity. Therefore, when inspecting geometrically complex components, it is advisable to disassemble some foreign objects from them, if of course possible. If disassembly cannot be performed, these negative effects must be taken into account in the measurement.

Faults of the inspected material - during the operation of the device, faults may occur in the structure of the material (fatigue cracks, corrosion, etc.). However, the material may also contain internal defects that have arisen in the production process (inclusions, deformations...).

Marginal influence of the inspected material when inspecting components with complex geometry, false indications may occur, which appear as places with failure. Therefore, it is necessary to use special probes designed for a specific component with such components

Dimensions of the material failure - the size and location of the failure has an effect on the change of eddy currents. The best detectable perturbation is one that is perpendicular to the flowing eddy currents. If the fault is longer than wider, eddy currents may not be bypassed, but underflow. Therefore, two-dimensional movement of the probe (coil) over the defective material is required during inspection, which increases the possibility of detecting the defect.

Signal display and evaluation - the obtained measured signals must be correctly interpreted and evaluated. The comparison method of signal evaluation consists in comparing the signal with and without a fault. The difference between the measured signals can then be displayed in the time and frequency plane. A complex plane impedance diagram is used to display harmonically excited signals.

However, further measurements are needed, which we want to make subsequently, in order to improve the identification of the actual failures caused by the corrosion of aircraft structures and not just the corrosion simulated in this way.

\section{CONCLUSION}

The purpose of non-destructive testing is to detect any material failure, to determine the type of such failure, and to describe its position and size. With this information, it is then possible to evaluate whether the component to be inspected can be repaired by a suitable method or to replace it with a new component.

The currently used methods of defectoscopy are in most cases sufficient to obtain this data, but many times the measurement is very complex, expensive or time consuming. Therefore, newer and more sophisticated flaw detection instruments and inspection procedures are being developed.

The paper deals with modern methods of eddy current testing, which are among the most widespread non-destructive techniques. Eddy current testing reveals hidden cracks and corrosion. The advantage of this technique over other non-destructive techniques is the ability to control through non-conductive materials, to determine the alloy composition and its hardness. Eddy current testing is a versatile method for controlling various materials. However, the condition is that the materials are electrically conductive and can generate eddy currents.

In summary, non-destructive eddy current testing provides industry with reliable information on the occurrence of various undesirable material and component anomalies. With the development of new materials used also in aeronautical technology, there is a continuous development of new techniques for reliable control of these materials. In recent years, excellent improvements have been made to this non-destructive technique and it can be said that improvements will continue.

\section{REFERENCES}

1. Holoda, Š., et al.: Modification in Structural Design of L-13 "Blanik" Aircraft's Wing to Obtain Airworthiness. TRANSCOM 2017: International scientific conference on sustainable, modern and safe transport, vol. 192, pages 330-335.

2. Beňo, L.; Bugaj, M.; Novák, A.: Application of RCM principles in the air operations. Komunikacie 2005, 7 (2), 20-24.

3. Bugaj, M.: Failure analysis-basic step of applying reliability centered maintenance in general aviation. Transport Problems 2012, 7 (1), 77-86.

4. Bugaj, M., et al.: Analysis and implementation of airworthiness directives. Transport Means, Proceedings of the International Conference, Volume 2018, p. 1174-1178.

5. Fahr, A.: Aeronautical Applications of Non-destructive Testing. 2014, DEStech Publications, Inc. ISBN 9781605 951201.

6. Lüthi, T.: Non-Destructive Evaluation Methods, 2013, https://www.pdfdrive.com/non-destructive-evaluationmethods-d38650200.html (accesed 1 Apr 2020). 
7. Janovec, M., et al.: Eddy Current Array Inspection of Zlin 142 Fuselage Riveted Joints. Transportation Research Procedia 2019, 40, 279-286.
8. Smetana, M., et al.: Identification of biomaterial fatigue cracks by ECT method, In: Electromagnetic nondestructive evaluation (XIX). Amsterdam: IOS Press BV. ISBN 9781-61499-638-5, Studies in Applied Electromagnetics and Mechanics 2016, 41, 223-229. 